\title{
Editorial: Meso- and Microscopic Structures: Implications for Tectonics
}

\author{
Tapas Kumar Biswal ${ }^{1 *}$, Bernhard Grasemann ${ }^{2}$ and Sebastian Oriolo ${ }^{3}$ \\ ${ }^{1}$ Department of Earth Sciences, IIT Bombay, Mumbai, India, ${ }^{2}$ Department of Geology, Faculty of Earth Sciences, Geography and \\ Astronomy, University of Vienna, Vienna, Austria, ${ }^{3}$ Universidad de Buenos Aires, Instituto de Geociencias Basicas, Aplicadas y \\ Ambientales de Buenos Aires(IGEBA), Buenos Aires, Argentina
}

Keywords: deformation structure, tectonics, orogeny, geochronology, exhumation

\section{Editorial on the Research Topic}

Meso- and Microscopic Structure Implications for Tectonics

Orogens are the product of subduction and collision of oceanic and continental plates. Meso- and microscopic structures, such as folds, shear zones, faults and foliations, are important structural elements that can be utilized in unraveling the geodynamic evolution of an orogeny, and are coupled with metamorphism and magmatism. For this reason, the research topic "Meso- and Microscopic Structures: Implications for Tectonics" aimed to study crustal dynamics using deformational structures from multiple analytical perspectives. Four manuscripts were finally included following the review processes, which focus on monazite microstructures, migmatite thickness distribution, brittle deformation of eclogites and the timing of orogenic events.

Subduction of oceanic crust is a critical factor that controls dynamics of active margins and continental assembly. The subducted slab undergoes high pressure (HP) metamorphism as it descends downward. During this process, the slab is dehydrated and undergoes both ductile and brittle deformation, being the latter characterized by micro- and meso-fracturing that controls seismic activity (Behr et al., 2018). A very informative exposure of the Tsäkkok Lens of the Scandinavian Caledonides was studied by Bukała et al. (this volume). The Tsäkkok eclogite is an exhumed HP rock (Barnes et al., 2020), which is dominated by brittle deformation (micro- and meso-scale fracturing) and only exhibits minor ductile. The high pore fluid pressure generated from the dehydration of lawsonite and glaucophane induced brittle fracturing in garnet. P-T conditions of micro-fracturing, which creates deep-seated seismicity along the subduction zone, are determined at ca. $2.42 \mathrm{GPa}$ at $635^{\circ} \mathrm{C}$.

On the other hand, subduction and subsequent collision create regional-scale orogens, which are particularly widespread during supercontinent assembly. The Neoproterozoic South Delhi orogeny (India) is a particularly well-documented case study, where protracted deformation, metamorphism and granite intrusion are indicated by zircon and monazite petrochronological data (Behera et al., 2019; Singh et al., 2020). Singh et al. (this volume) provide a multiproxy approach to disentangle the complex evolution of the Delhi orogeny of northwestern India. The Aravalli-Delhi Mobile Belt of northwestern India has experienced a polyphase Neoproterozoic evolution, evaluated based on coupled structural and microstructural analysis with petrochronological data. Protracted granite intrusions occurred during the Neoproterozoic, being partially coeval with the early phase of deformation at ca. $880 \mathrm{Ma}$ and further multiple events occurring up to ca. 588-564 Ma, thus suggesting that the South Delhi orogeny was synchronous with the Pan-African orogeny. 
From a petrochronological perspective, monazite is extremely useful for dating orogenic events. Though it has a high closure temperature for U-Th- $\mathrm{Pb}$ diffusion, mechanisms such as dislocation creep and, particularly, dissolution-reprecipitation, allow monazite growth under variable to fluid-assisted metamorphic conditions (Harlov et al., 2011; Wawrzenitz et al., 2012). Schulz (this volume) provides a thorough review of monazite microstructures of igneous (e.g., granites) and granulite, amphibolite and greenschist facies metamorphic rocks. The genesis of microstructures, such as coronas, satellite and cluster microstructures, are particularly discussed, emphasizing their relevance to reconstruct P-T paths based on monazite equilibrium conditions. Finally, the role of monazite microstructures and petrochronology to understand large-scale tectonic and geodynamic processes is highlighted.

Several orogens are characterized by migmatitic terranes, which are products of high $\mathrm{P}-\mathrm{T}$ conditions and anatexis (Sawyer, 2008). The distribution of leucosomes in migmatite bands, commonly attributed to a power-law distribution (Corral and González, 2019), provides information about accumulation and transport mechanisms during anatexis. Saukko et al. (this volume) show also the presence of double power-law distribution in

\section{REFERENCES}

Barnes, C. J., Jeanneret, P., Kullerud, K., Majka, J., Schneider, D. A., Bukala, M., et al. (2020). Exhumation of the High-Pressure Tsäkkok Lens, Swedish Caledonides: Insights From the Structural and White Mica 40Ar/39Ar Geochronological Record. Tectonics 39 (7), e2020TC006242.

Behera, B. M., Waele, B. D., Thirukumaran, V., Sundaralingam, K., Narayanan, S., Sivalingam, B., et al. (2019). Kinematics, Strain Pattern and Geochronology of the Salem-Attur Shear Zone: Tectonic Implications for the Multiple Sheared Salem-Namakkal Blocks of the Southern Granulite Terrane, India. Precambrian Res. 324, 32-61. doi:10.1016/ j.precamres.2019.01.022

Behr, W. M., Kotowski, A. J., and Ashley, K. T. (2018). Dehydration-Induced Rheological Heterogeneity and the Deep Tremor Source in Warm Subduction Zones. Geology. 46, 475-478. doi:10.1130/G40105.1

Corral, Á., and González, Á. (2019). Power Law Size Distributions in Geoscience Revisited. Earth Space Sci. 6 (5), 673-697. doi:10.1029/2018EA000479

Harlov, D. E., Wirth, R., and Hetherington, C. J. (2011). Fluid-mediated Partial Alteration of Monazite, Monazite: the Role of Coupled DissolutionReprecipitation during Apparent Solid-State Element Mass Transfer. Contrib. Mineral. Petrol. 162, 329-348.

Sawyer, E. W. (2008). Working with Migmatites: Nomenclature for the Constituent parts." in Working with Migmatites. Editors E. W. Sawyer and M. Brown Quebec City, Canada: Mineralogical Association of Canada. $38,1-28$. the Plkiluoto migmatite of western Finland. Based on numerical modeling for the different distribution systems of the migmatites, they infer different mechanisms to explain the double power-law distribution, such as impediments on the bottom-up self-organized criticality of melt transport, and melt accumulation in channels, and sudden melt removal.

The papers were reviewed by Luca Menegon, University of Oslo, Norway; Simona Ferrando, University of Turin, Italy; Junpeng Wang, China University of Geosciences, Wuhan, China; Christoph Von Hagke, RWTH Aachen University, Germany; Sergio Llana-Fúnez, University of Oviedo, Spain; Paul Dirk Bons, University of Tübingen, Germany; Alfonso Sola, Consejo Nacional de Investigaciones Científicas y Técnicas (CONICET), Argentina and several anonymous reviewers. Manuscript editors were Bernhard Grasemann, Sebastián Oriolo, and Guillermo Booth-Rea.

\section{AUTHOR CONTRIBUTIONS}

All authors listed have made a substantial, direct, and intellectual contribution to the work and approved it for publication.

Singh, S., Shukla, A., Umasankar, B. H., Biswal, T. K., Biswal, T. K., et al. (2020). “Timing of South Delhi Orogeny: Interpretation From Structural Fabric and Granite Geochronology, Beawar-Rupnagar-Babra Area, Rajasthan, NW India," in Society of Earth Scientists Series, Structural Geometry of Mobile Belts of the Indian Subcontinent (Switzerland: Springer Nature AG). doi:10.1007/978-3-030-40593-9_1

Wawrzenitz, N., Krohe, A., Rhede, D., and Romer, R. L. (2012). Dating Rock Deformation with Monazite: The Impact of Dissolution Precipitation Creep. Lithos. 134-135, 52-74. doi:10.1016/j.lithos.2011.11.025

Conflict of Interest: The authors declare that the research was conducted in the absence of any commercial or financial relationships that could be construed as a potential conflict of interest.

Publisher's Note: All claims expressed in this article are solely those of the authors and do not necessarily represent those of their affiliated organizations, or those of the publisher, the editors and the reviewers. Any product that may be evaluated in this article, or claim that may be made by its manufacturer, is not guaranteed or endorsed by the publisher.

Copyright (c) 2021 Biswal, Grasemann and Oriolo. This is an open-access article distributed under the terms of the Creative Commons Attribution License (CC BY). The use, distribution or reproduction in other forums is permitted, provided the original author(s) and the copyright owner(s) are credited and that the original publication in this journal is cited, in accordance with accepted academic practice. No use, distribution or reproduction is permitted which does not comply with these terms. 